\title{
DEVELOPMENT OF AN ECO-BUSINESS DIRECTORY: APPROACHES AND CHALLENGES
}

\author{
U A D Prasanthi Gunawardena', A P de Alwis² and A M I U Seneviratne \\ 'Department of Forestry and Environmental Science, University of Sri Jayewardenapura \\ 2Department of Chemical and Process Engineering, University of Moratuwa.
}

Eco-business is the provision of products and services that are environmentally friendly. When the preferences of the society are heading towards environmental safety, manufacturers need to adjust their production and marketing strategies to respond to this change in consumer preferences. Eco-business aims at exploiting the market mechanism to provide the market with more environmentally responsible products. This study presents the approaches used and challenges faced in the development of an eco business directory for Sri Lanka.

The building of the preliminary model for an eco business directory was done with the help of five types of surveys. Firstly, an island-wide industrial survey has been carried out which included major industries, hotel industry and minor industries. Secondly, an expert opinion survey was carried out to review the existing situation on a sectoral basis regarding eco-friendly products/services and to explore the possibilities and recent developments of new products and services. Thirdly, a survey of existing literature was done in order to understand experiences regarding eco-friendly products in different contexts. In addition, NGO activities related environment has been collected in order to identify gaps in public participation. In addition, available financial mechanisms for eco industries have also been listed.

The main challenges faced in the preparation was the limited response from the relevant parties for the surveys. The lack of awareness on the 'eco friendly' products and services was another issue which need further theoretical and practical definitions

If eco ousinesses are to be establisıed as a complete business surategy, environmental claims had to be accurate and independently substantiated. It is not likely that market place would resolve these problems on its own. The paper elaborates on the necd of guidelines and specifications on eco friendly products and services.

Proceedings of the Ninth Annual Forestry and Environment Symposium 2003 of the Department of Forestry and Environmental Science, University of Sri Jayewardenepura, Sri Lanka 